\title{
Birlikte Yaşama Tecrübesine ve Ortak Yaşam Alanına İşaret Eden Kavramsal Bir Çalışma: Ebrulî Kültür (Mardin Örneği)
}

Öz: Bir toplumdaki etnik ve dinî çeşitliliği ifade etmek için genellikle çokkültürlülük kavramı kullanılmaktadır. Bu kavram, iç dinamikleri tanımlamada yetersizdir. Bu nedenle Mardin örneğinde yeni bir kavrama odaklanılmıştır: Ebrulî kültür. Kavramsallaştırmada “değer” yaklaşımı esas alınmıştır. Makalede ebrulî kültür kavramını açıklamak ve bundan hareketle farklı etnik ve dinî grupların yüzyıllara dayanan etkileşim dinamiğine işaret etmek amaçlanmıştır. Bu amaçla mozaik, gökkuşağı ve melez gibi kavramlar sorgulanmıştır. Bu kavramlar Türkiye'deki sosyo-kültürel dinamikleri tanımlamada yetersiz olarak değerlendirilmiştir. Ayrıca Türkiye'deki farklı etnik ve dinî gruplar arası etkileşimin "değer” üzerinden inşa edildiği vurgulanmıştır. Bu etkileşim biçimi, uzun tarihî geçmişe dayanmasına rağmen günümüzde değişmektedir. Bununla birlikte, sosyokültürel alana dönük iyileştirmelerin "değer" merkezli yaklaşımlarla ele alınması gerektiği sonucuna da ulaşılmıştır.

Anahtar Kelimeler: Ebrulî Kültür, Mozaik, Ortak Yaşam, Değer, Mardin.

\section{A Conceptual Study Pointing to the Experience of Living Together and Common Life Area: Ebrulî Culture (Example of Mardin)}

\begin{abstract}
The concept of multiculturalism is, often used to express ethnic and religious diversity in a society. This concept is insufficient to describe internal dynamics. For this reason, we have focused on a new concept in the example of Mardin: Ebrulî Culture. In the conceptualization process, we took "value" approach as basis. In the study, we aimed to explain the concept of Ebrulî Culture and point out the dynamics of interaction of different ethnic and religious groups for centuries. For this purpose, we questioned some concepts such as mosaic, rainbow and hybrid. We concluded that these concepts are insufficient to describe the sociocultural dynamics in Turkey. In addition, we emphasized that the interaction among different ethnic and religious groups is constructed
\end{abstract}

Dr. Öğr. Üyesi, Mardin Artuklu Üniversitesi Edebiyat Fakültesi Antropoloji Bölümü, halityesilmen@artuklu.edu.tr Orcid: https://orcid.org/0000-0002-4907-1366 
based on "value" in Turkey. However, this type of interactions change nowadays, even though it has a long history. Moreover, we reached the result that the socio-cultural improvements need to be addressed with the basis of "value" approaches.

Keywords: Ebrulî Culture, Mosaic, Common Life, Value, Mardin.

\section{Giriş}

Modernleşme ve küreselleşme sürecinde Türkiye, sosyo-kültürel olgulara dönük Batı merkezli işlenen ve oradan dünyaya yayılan literatürü ve kavramları kullanagelmiştir. Bu bir yönüyle kaçınılmazdır fakat kavramların sosyo-kültürel alana ne kadarıyla işaret edebildiği sorgulanmalıdır. Bu açıdan makalede, Türkiye'deki mevcut etnik ve dinî grupların ortak yaşam tecrübesini vurgulayan yeni bir kavrama yer verilmiştir: Ebrulî Kültür. Ebrulî kültür kavramının hangi yönleriyle ortak yaşam alanına işaret edebildiği sorgulanmaktadır. Bu sorgulama sırasında Mardin örneği üzerinden ebrulî kültür kavramıyla işaret edilen etkileşimlerin temel özellikleri ortaya konmaya çalışılmakta ve bir takım hassasiyetlere dikkat çekilmektedir.

Çokkültürcülük politikalarıyla Batı ülkeleri, siyasi yasalar yoluyla farklı grupların ve ulusların etkileşimlerine alan açarak sosyal mutabakat ve entegrasyon için bir takım düzenlemelere ihtiyaç hissetmektedirler (Berry, Poortinga, Breugelmans, Chasiotis ve Sam, 2015: 339-340; Kymlicka, 2015: 40-43). Bu bağlamda Türkiye, Batı ülkeleriyle aynı tarihi geçmişi paylaşmamaktadır. ${ }^{2}$ Mardin örneğinden hareketle Araplar, Kürtler ve Süryaniler (Hristiyanlar) gibi farklı etnik ve dinî unsurların yüzyıllara varan birlikte yaşama tecrübesi hesaba katıldığında çokkültürlülük, mozaik ve melez gibi kavramlar üzerinden Türkiye'deki sosyo-kültürel yapıyı tanımlamanın yetersiz olduğu söylenebilir. ${ }^{3}$

Görece etkileşimler söz konusu olmakla birlikte genel olarak Türkiye, özelde ise Mardin ve çevresi farklı etnik ve dinî unsurları içinde barındırmaktadır. Bu unsurların arasında çapraz kategorizasyon biçiminde tanımlamalar söz konusu olmuş, etnik-içi grupların diğer etnik-içi gruplarla diyakritik (ayırt edici/eleştirel) yoruma dayalı etkileşimleri günümüze kadar taşınabilmiştir. Bu etkileşimler, “değer” merkezli olmak üzere ortak bir ufkun ve kültürün oluşmasına neden olmuştur. Mardin, bu yönüyle canlılığını hala koruyarak gündemde yer aldığı ve kavramsallaştırmaya uygun örnekleri -azalarak da olsa- barındırdığı için ön planda tutulmuştur.

Ebrulî, alegorik biçimde farklılıkların (renklerin) ortak zemindeki konumlanma durumuna gönderme yapmaktadır. Değer kavramı ise ebrulî kültürdeki farklı etnik ve dinî unsurların karşılıklı dinamiklerini açıklamaya dönük değerlendirilmektedir. Ebrulî kültür kavramı, özellikle antropolojik bir yaklaşımla

\footnotetext{
2 Savaş nedeniyle Suriye ve Iraktan Türkiye'ye gelen göçmen/mülteci/misafir gruplar makalede söz konusu edilmemiștir.

3 Ortaylı (2001: 19), farklı kavramlar üzerinden yaptığı değerlendirmelerde bu şekildeki kullanım yetersizliğini/hatalarını "terim ve tarihi uyuşmazlık” olarak nitelemektedir.
} 
değer, değmek, diğer ve değişmek olgularıyla ilişkili ele alınmaktadır. Bununla birlikte bu kavram, uzun tarihî geçmişe, birikerek gelen yaşam tecrübesine ve "diyakritik yorumbilgisi”" ${ }^{4}$ yaklaşımıyla sürdürülebilir etkileşimlere dayandırılarak kavramsallaştırılmaktadır. Çeşitli sosyal krizlerin de yaşanabildiği bu kültürde, krizlerin ve çatışmaların aşılmasını sağlayan kuşatıcı değer(ler)in azalarak da olsa günümüze kadar geldiği söylenebilir.

Melez ve mozaik ifadelerine kıyasla, yabancı yazında ebrulî kültür kavramını yakın olarak karşılayan "variegated culture" (renkli/rengarenk kültür) ifadesinden bahsedilebilir (Halliwell'in, 2007: 20). Burada farklı kültürlerin birlikteliği, elit kültürün katmanlaştırıcı belirleyiciliğinden uzak bir şekilde tanımlanmaya çalışılmaktadır.

Yerel literatürde ebrulî ifadesi, Mardin'deki farklı enik ve dinî grupların ahenkli birlikteliğine vurgu yapmak için daha önceki çalışmalarda kullanılmıştır. Farklılıklar arasındaki ahenkli durum, sanatsal bir şekilde ebru sergisine ve "Ebrulî Mardin" (Barutçugil, 2010) adlı çalışmaya konu olmuştur. Bunun dışında Tarhan (2010: 255-256) da "gruplar arasındaki diyalog" perspektifinden üç tip toplum koalisyonuna değinirken "ebru” ifadesini kullanmaktadır: Gökkuşağı, mozaik ve ebru. Gökkuşağı, Avrupa örnek verilerek renkler arasındaki hiyerarşik bir konumlanmaya; mozaik ifadesi, $A B D$ ve Sovyetler Birliği örneği ile zayıf bir bağ ve görece yalıtılmış bir konumlanmaya; "ebru koalisyonu" ise Osmanlı örneği üzerinden birbirinden ayrılamayacak derecedeki yatay etkileşimlerle yoğrulmuş bütünlüğe göndermeyle kısaca açıklanmaktadır.

Ebrulî kültür kavramı, "Mahallemiler” (Yeşilmen, 2017) adlı çalışmada da önerilmiştir. Makalede ise bu kavram, geniş ve ayrıntılı bir şekilde açıklanmaya çalışılmaktadır.

Batılı araştırmacılar, sosyo-kültürel yapılarına dönük farklılıkların etkileşimini, alışverişini ve neticede oluşan kolektif zihniyet evrenini ifade etmek için genellikle melez kavramını kullanmaktadırlar. Bourse'nin (2009) ve Burke'nin (2011) çalışmaları bunlara örnek verilebilir. Bu örneklere Göle de eklenebilir. Göle (2008), "Melez Desenler" adlı çalışmasında, melez olgusunu iki yönden ele almaktadır: Birincisi, negatif yönüyle, soy saflığının yokluğuyla neticelenen ve köken belirsizliğini/gerginliğini vurgulayan melezlenme; ikincisi ise birlikte yaşamanın, öğrenmenin, birbirinden etkilenmenin bir koşulu olarak melezlenme. Bu nitelikteki çalışmalarda melez olgusu; safıł üzerinden, daha doğrusu saf ırk

\footnotetext{
${ }^{4}$ Bu yaklaşımda Kearney'in (2012) değerlendirmeleri göz önünde bulundurulmaktadır. Kearney, konuyla ilgili hem olgusal hem de Batı kültürünün öteki sorunsalını aşmaya dönük değerlendirmeler yapmaktadır. "Öteki”nin korkular üzerinden şeytanlaştırıldığını belirten Kearney, değerlendirmelerinde "romantik" ve "radikal yorumbilgisinden" ayrı üçüncü yolu izlemektedir. Romantik yorumbilgisinde iki özne bilincinin "birleşmesi” söz konusudur ki, bu bir yönüyle "mutlak aşinalık" anlamında değerlendirilmektedir. Radikal yorumbilgisinde ise "indirgenemez bir farklılık", ayrılık, mutlak yabancı veya "sonsuz başkalık" söz konusudur. Kearney ise diyakritik yorumbilgisi yaklaşımıyla mutlak aşinalığın ve mutlak yabancının olmadığını vurgulayarak "farklı olmakla beraber birbirine benzetilebilen benlikler arasında kurulabilecek karşsılılı ilişkileri” incelemektedir. Bu açıdan Kearney, “benin içindeki yabancıyı ve yabancının içindeki beni” açıklamaya çalışır (Kearney’in, 2012: 31-34).
} 
ölçüsü üzerinden değerlendirilmektedir. Ebrulî kültür kavramsallaştırmasında ise merkeze alınan husus; tarihî kökleri yadsımayan, aynı zamanda karşııılı etkileşimleri belirleyen, kültür dinamiğine içkin değer yaklaşımıdır.

Türkiye'deki sosyo-kültürel yapıya işaret etmek için melez kavramının yanı sıra daha çok mozaik kavramına başvurulmaktadır. Mardin ve Hatay gibi çeşitli etnik ve dinî farklılıkları yoğun biçimde bünyesinde taşıyan şehirlerin sosyokültürel yapılarına dönük çalışmalarda, mozaik kavramı kullanılmakla birlikte şehirlerin kendine has özelliklerine de dikkat çekilmektedir (Doğruel, 2013: 243; 273). Doğruel'in (2013) “Insaniyetleri Benzer...” adlı çalışması buna örnek verilebilir. Ebrulî kültür kavramsallaştırmasını konu alan bu makale, mozaik konumlanmanın ötesindeki özgül yapıyı tanımlamada tamamlayıcılık niteliğini taşımaktadır.

Türkiye'nin kültürel yapısını ifade etmek için mozaik kavramının kullanılmasına doğrudan karşı çıkanlar da bulunmaktadır. Yuvalı (1996) ve Türkdoğan'ın (1999) çalışmaları buna örnektir. Bu çalışmalarda kültür dinamiğinin, statik bir niteliğe işaret eden mozaik kavramıyla açıklanamayacağı, Türkiye’ye dönük bu kullanımın "kavram kargaşası”ndan ve oryantalizm merkezli "sulandırıcı" yaklaşımlardan kaynaklandığı vurgulanmaktadır (Yuvalı, 1996: 212; Türkdoğan, 1999: 14-15). Yuvalı ve Türkdoğan'ın çalışmalarında Türkiye'deki farklı etnik ve dinî unsurların yüzyıllar boyunca karşılıklı etkileșimlerde bulundukları ve özgül bir mayaya sahip oldukları çeşitli örneklerle belirtilmektedir. Bunların dışındaki birçok çalışmada da Türkiye'nin özgül yapısının belirtilmesi açısından mozaik, melez ve gökkuşağı gibi kullanımların yetersizliği bir şekilde ifade edilmektedir. Fakat kavramsallaştırma eksikliğinin olduğu dikkat çekmektedir. Bu açıdan makalede ebrulî kültür kavramı önerilmektedir. Ebrulî kültür kavramı, dinamik boyutuyla kültür olgusuna, ortak yaşam alanına ve birlikte yaşama tecrübesine dönük Türkiye'nin özgül yapısına gönderme yapmaktadır.

\section{Sebepler}

Çokkültürlülük Bağlamında Yeni Bir Kavram ihtiyacını Gerektiren Temel

Kavram sorunsalı, ekseriyetle konuşulan konu ile işaret edilen alan arasındaki mesafenin artmasına ve beklenmedik çeşitli problemlere sebep olabilmektedir. Bu durum, çokkültürcülük (multiculturalist) tartışmalarıyla birlikte dünyada yükselişe geçen çokkültürlülük (multiculturalness), mozaik, melez ve gökkuşağı kullanımları için de geçerlidir.

Çokkültürcülük, farklı kültürel grupların ve bireylerin aynı çatı içindeki siyasi tanınma hakları ve bu farklılıkların yasal güvenceye alınma gerekliliği ile ilgilidir (Taylor vd., 2014: 46; Kymlicka, 2015: 50-53). Çokkültürlülük kavramı ise bir toplumun içindeki değer, inanç ve etnik gruplar gibi farklılıklara dönük çeşitliliği 
ve/veya bu çeşitliliği -yeniden üretilen kimliklenmeler yoluyla- talep etme durumunu vurgulamak için kullanılır (Berry vd. 2015: 338). ${ }^{5}$

Çeşitlilik olgusu itibariyle çokkültürlü toplumlar, modern ulus-devlet yapılarından önce de söz konusudur. Çokkültürlülük, Kılıçbay'ın ifadesiyle "tarih boyunca var olan ve devlet kuracak kadar karmaşık ilişkiler ağı kurmuş her toplum için" tabiatı gereği zorunludur. Dolayısıyla çokkültürlülük, talep edilecek bir durum değildir. Çünkü yapısı gereği toplumlar, bu özelliği kendi içinde barındırmaktadır (Kılıçbay, 1998: 172). ${ }^{6}$

Batı ülkelerindeki ilgili tartışmalar, dikey (siyasi ve tarihî) ve yatay (karşıııkı etkileşimler) düzlemde entegrasyonel dengeyi ve farklı kültürlerin devamlılığını vurgulamak içindir (Berry vd., 2015: 339-340). Bu yöndeki tartışmalar, C. Taylor Berry ve Kalin- ile birlikte farklı kültürel grupların kamusal kabulü ve algısı üzerinden başlayarak devam etmiştir (Berry vd., 2015: 341). Taylor, bireysel kimliğin inşasında kültürel kimliklerin vazgeçilmez olduğunu ve bunun diyalojik olarak diğerleriyle ve özellikle de kültürel grup-içi dinamiklerle sağlıklı bir şekilde gerçekleşebileceğini vurgulamaktadır. Bu çerçevede, hem birey hem de grup için önemsenen ve ancak kültürel kimliğin dinamiklerince içkin olarak sağlanabilecek olan "şeref" olgusunun önemine işaret etmektedir. Taylor, bu sürecin ahlak ve sahicilik problemini de dikkate almaktadır. Kültür çeşitliliği, bir imkân yaklaşımıyla daha derin ve aynı zamanda kuşatıcı bir ufuk için araç olarak değerlendirilmekte, Gadamer'in "ufukların kaynaşması” yaklaşımı da hatırlatılmaktadır (Taylor, 2014: 52-93). Bu tartışmalarda değinilen hassasiyetler, makale içerisinde, ebrulî kültürdeki değer dinamikleri özelinde imlenmeye çalışılmaktadır.

Belirtilen tartışmalar bağlamında şunun belirtilmesi gerekir ki, tarihî arka plan itibariyle Türkiye'nin çokkültürlü alanı, Batı ülkelerinden farklıdır. Tarihî arka plan itibariyle ilkin, Batı ülkelerinin çokuluslu devlet yapısına sahip olmaları hususu zikredilebilir. Birçok Batı ülkesi çokulusludur. ABD buna örnektir (Kymlicka, 2015: 40-42). Söz konusu edilen "çokuluslu” nitelemesi, önceden kendine has sosyo-politik örgütlenmeye sahip farklı grupların/ulusların, sonradan tek bir çatı altında toplanmalarına ilişkin bir durumdur ve aynı zamanda aşağıda açıklanacağı gibi mozaik konumlanmaya gönderme yapmaktadır. Bununla birlikte, çokkültürcülük politikalarının ekonomiyle içkin biçimde "Avrupalı" veya "Amerikalı" üst kimliğini oluşturmaya dönük yapısal bir düzenleme olduğu söylenebilir. Bu çerçevede çokkültürcülük politikalarını tek çatı entegrasyonu bağlamında ekonomik, siyasi ve kültürel sorunları aşmak için uygulanan bir yapılanma biçimi olarak değerlendirmek mümkündür.

\footnotetext{
5 Kavram olarak çokkültürcülük, İngilizcede ilk kez 1941 yılında, kozmopolit bir toplumu nitelemek için kullanıldı. 1970'li yılların başlarında ise ilk defa Avustralya ve Kanada'da azınılı ve göçmenlerin kültürel çeşitliliğine dönük devlet politikaları için kullanılmaya başlandı. Sonraki on yılda bu terim, ABD, Britanya, Yeni Zelanda, Avrupa ve Latin Amerika'ya yayıldı. Bu zaman diliminde sözlükte geçmeyen bu kavram, nihayet 1989 yılında Oxford İngilizce Sözlük'te yerini alabildi (Doytcheva, 2009: 12-16).

${ }^{6}$ Bazı yaklaşımlarda çokkültürlülük kavramı, kültürel olarak çeşitliliği ifade etmekten ziyade tercih olarak çok kültürlülüğün teşvik edilmesi yönünde açıklanmaktadır. Başka bir deyişle, kültürel çeşitliliğin nasıı anlaşılacağı yönünde de tartışmalar kendini gösterebilmektedir (Berry vd., 2015: 339).
} 
Çokkültürcülük kavramının ikinci temel tarihî kaynağı ise uluslararası göçtür. Göç, çok sayıda kişi veya ailelerden oluşan göçmen gruplardan oluşmaktadır. ${ }^{7}$ Bu nitelikteki göç dalgaları Avusturya, Kanada ve ABD için her zaman önem taşımaktadır. Çünkü dünyadaki göçlerin yarıdan fazlası bu ülkelere yapılmaktadır. Bu durum İngiltere ve Fransa gibi ülkeler için de geçerlidir (Kymlicka, 2015: 40-50; Doytcheva, 2009:10-11). Batı ülkelerindeki göçmenlerin nüfus hareketliliği, onların geniş toplumla adaptasyonunu çeşitli faktörlerle sorun haline getirmiş ve süreç içerisinde çokkültürcülük çerçevesindeki tartışmalar kaçınılmaz olmuştur.

Çokkültürlülük kavramının genel kullanım çerçevesini ve Batı ülkelerindeki temel tarihî arka planını belirttikten sonra problemin anlaşılabilirliğini açıklayabilmek için melez, mozaik ve gökkuşağı kullanımlarına da değinmek gerekir.

Irka gönderme yapan melez (hybrid/metis) kelimesi, ayrı ırklardan olan anne-babadan doğan çocuklar için kullanılmaktadır. Fransızcada melez kavramı, insanlar için métis; bitki ve hayvanlar için hybride; beyaz (ak) ve zenci (kara) ırkların karışımında ise mulâtre ifadeleriyle dile getirilmektedir (Hançerlioğlu, 2012: 127). Bu kavramın ABD ve Avrupa ülkelerinin siyasi, tarihî ve sosyo-kültürel anlam bağlamlarına uygun olduğu söylenebilir. Her şeyden önce bu kavram, ırksal durumlara işaret etmektedir.

Bir sanat türünü ifade eden moza(y)ik kavramı ise Türkçe sözlükte şu anlamda yer almaktadır: "1- Küçük ve renkli taş veya cam parçaları ile yapılan duvar resmi veya zemin döşemesi. 2- Çimento içine küçük mermer parçaları katılarak meydana getirilen zemin veya merdiven döşemesi. 3- Bu döşemeyi yapmakta kullanılan mermer parçaları." (Doğan, 2008: 1157). Bu anlamlara göre mozaik ifadesi, kültürel etkileşimlere işaret etmekten ziyade donuk bir konumlanma biçimini göstermektedir. Dolayısıyla analitik bir değer olarak mozaik ifadesinin tek çatı altındaki farklı ulus ve grupların görece yalıtılmış, mesafeli ve çoklu konumlanmalarına işaret ettiği söylenebilir. Bu yönüyle çokkültürcülük politikalarını da mozaik mesafeleri birbirine “değer"li (ebrulî) kılma gayretleri olarak yorumlamak mümkündür.

Mozaik mesafesine kıyasla gökkuşağı konumlanması ise nispeten biraz daha yumuşatılmış esnek kabulleri içermektedir: ${ }^{8}$ Yan-yanalık durumunun kabul edilmiş halini açıklar, buna rağmen farklılıkların (renklerin) etkileşim problemi devam etmektedir; burada etkileşimlerin sürdürülebilirlik esası yoktur. Gökkuşağı mesafesinde farklılıklar arasında kabul görmüş, nostalji ve turizm cazibesinde bir yan-yanalık vardır. Mozaik durumda ise kabul sorunsalı hala söz konusudur.

\footnotetext{
7 Burada söz konusu olan göç, daha çok ekonomik sebeplerle vuku bulan nüfus hareketliliğidir. Irak ve Suriye örneğinde olduğu gibi savaşın sebebiyet verdiği göçler (mülteci hareketliliği) ayrı bir değerlendirme konusudur.

8 Gökkuşağı değerlendirmesi için ayrıca bkz. (Tarhan, 210: 255-256).
} 
Yukarıda ifade edildiği gibi Batı ülkeleri, farklı unsurların etkileşimlerini siyasi(dikey) ve sosyal(yatay) düzlemde ayrımcılıktan uzak ve değerli hale getirmeye çalışmaktadır. Türkiye ise hem tarihî arka planı hem de sosyo-kültürel yapısı bakımından Batı ülkelerinden farklı bir durum arz etmektedir. İdealize niteliğindeki çokkültürcü yaklaşımlar, Türkiye'deki dinamikler itibariyle yeni, icat edilmiş kimliklenmelere yol açacağı gibi ebrulî kültür içindeki konumlanmayı mozaik yapıya dönüştürebilir. Kimlik, "bilince yükselme" yoluyla oluşur (Assmann, 2001:131-132). Bu itibarla söylemler, gruplar arası etkileșimleri doğrudan etkileyecektir. Uzun yıllara dayanan birlikte yaşama tecrübesine Batı merkezli çokkültürcü söylemlerle ve stratejik biçimde dokunmak (etnopolitikanın gerektirdiği konumlanmayla yani etnik bileşenleri kültürden ayıklayarak bilince yükseltmek), yaşanmışlık tecrübesini dönüştürmekle (mozaikleștirmekle) eşdeğerdir. Ebrulî kültür kavramsallaştırması, bu yöndeki hassasiyetlere dikkat çekmektedir. Kavramın içeriğini açıklamadan önce pratik yaşamdan bazı örnekler vermek konuya açıklık getirecektir.

\section{Birlikte Yaşama Tecrübesine Dair Ebrulî Kültürden Bazı Örnekler}

Mardin, farklı etnik ve dinî grupların değer merkezli etkileşimlerine ev sahipliği yapan bir il konumundadır. ${ }^{9}$ Köyler bağlamında düşünüldüğünde; birçok köyün kendi içindeki farklı akrabalık grupları arasında etkileşimler söz konusudur. Farklı etnik yapılara sahip olan köyler için de bu durum geçerlidir. Kürt kökenli olmasına rağmen Arap köylerinde yaşamını idame ettirmiş ya da Arap kökenli olup Kürt köylerinde yaşamını sürdüren aile/fert örnekleri fazlasıyla vardır. Bu durum, farklı etnik gruplar arasında akrabalık bağlarının oluşmasına ve etnisizmin aksine, hem köyler hem de etnik kimlikler itibariyle grupların birbirlerine dayıamca vurgusuyla hitap etmelerine sebep olmuștur. Benzer etkileşimlerle farklı etnik-içi grupların diğer etnik-içi gruplarla olan değer merkezli etkileşimleri de günümüze kadar taşınabilmiştir.

Diğer etnik grubun içine giden aile ve fertler, gittikleri etnik kültürü etkiledikleri gibi daha çok o kültürü özümsemişlerdir. Bu süreçte değişim kaçınılmazdır. Bu açıdan ebrulî kültürün asimilasyon kavramı üzerinden bir konumlanmayı veya etki-tepkiyi barındırmadığı da söylenmelidir.

Köyler arası göç, akrabalık bağları, ticaret ve komşuluk ilişkileri, bölgede kabul gören karizmatik dinî liderler, ziyaret ve mesire alanları, her kesime hitap eden şifaya dönük sağaltıcı yöntemler gibi değer merkezli etkileşimler, farklı etnik ve dinî grupların arasındaki sınırları geçişken kılarken aynı zamanda etkileşimleri de beslemektedir.

\footnotetext{
9 Mardin ve çevresi, geçmişten günümüze çeşitliliği azalarak da olsa Yahudiler, Hristiyanlar, Müslümanlar, Şemsîler, Yezidiler, Ermeniler, Araplar, Kürtler, Kareçiler ve Mıtırbiler gibi etnik ve dini grupların yaşam alanına sahne olmuştur. Farklı etnik ve dini kimliklerin, özellikle de farklı dini kimliklerin sosyo-kültürel alandaki etkileşimleri günümüze kıyasla geçmişte daha yoğundu. Bu açıdan günümüzdeki Mardin'i idealize etmek sakıncalı olabilir. Çünkü birlikte yaşama tecrübesini bugüne taşıyabilen anlam bağlamı ve refleksler giderek zayıflamaktadır.
} 
Ebrulî kültürde gruplar arası bir takım önyargılar ve stereotipler (kalıp yargılar) de söz konusudur, fakat ileride açıklanacağı üzere "değer” ve "diyakritik yorumbilgisi"ne dayalı etkileşimler esastır.

Gruplar arası krizler, genellikle iç-dış olmak üzere siyasi-politik manevralardan kaynaklı olmaktadır. Bununla birlikte ebrulî kültür, pek çok krizi kendi içinde aşarak günümüze kadar gelebilmiştir. Bu durum, etnik ve dinî gruplar arasındaki etkileşimler için de geçerlidir: ${ }^{10}$ Kürt, Arap ve Süryanilerin İngilizlere dönük 1918'deki mukavemetleri bunun bir göstergesidir (Dolapönü, 1972:102-103). Yapılan araştırmalar göstermektedir ki, XIX. yüzyılda Mardin'de, görece nüfus oranlarıyla sadece Müslümanların veya sadece gayrimüslimlerin yaşadığı izole mahalleler söz konusu değildir (Özcoşar, 2017: 11). Şer’iye sicilleri, Müslüman ve Hristiyanlar arasındaki birçok komşuluk örneklerinden bahsetmektedir. O dönemin mahkeme kayıtlarına göre din merkezli bir çatışmanın vuku bulmaması dikkat çekicidir. Siyasi düzenlemelerde bazı ayırt edici standartlar mevzubahis olsa da güncel yaşamda bu standartlar belirleyici olmamıştır (Öztürk, 2006: 521). Bir Müslümanın sabununu çalan gayrimüslim birinin kendi dindaşları tarafından şikayet edilmesi ve mahkemede aleyhine şahitlik yapılması; Müslüman bir kadının, eșini boşadıktan sonra gerekli mülkünü kocasından alamadığına dair açtığı davada vekil olarak Süryani Kadim Abdulahad Efendi'yi seçmesi; Müslümanlarla ilgili davalarda Keldani ve Süryani Katolik birinin görev alması gibi yaşanmışlık örnekleri, etkileşimlerin birbirini dışlama merkezinde cereyan etmediğini göstermektedir (Özcoşar, 2009: 103).

Günümüzde örnekleri olduğu gibi XIX. yüzyılda da Müslüman ve gayrimüslimlerin birbirlerine selam verdikleri Buckingham'ın kayıtlarında yer almaktadır. Buckingham (1827: 185), her ne kadar merhabalaşma telaffuzunu Müslümanların kullanım biçimi üzerinden "Salâm Alaikom" olarak aktarmaktaysa da Süryanilerin kendi içinde birbirlerine selam vermeleri de Müslümanların kullanımına yakın bir telaffuzla gerçekleşebilmektedir: "Şlomo" veya "Şlomo Ahlaykhu”. Bu yönüyle selamlaşmanın, Süryani ve Müslümanlar arasında değerli etkileşimlere alan açtığını söylemek mümkündür.

Süryani ve Müslümanların birbirlerinin taziyelerine ve davetlerine iştirak etmeleri, komşuluk ilişkilerinde bulunmaları gibi hususlar -örnekleri geçmişte daha fazla olmasına rağmen- Mardin ve ilçelerinde bilinen bir durumdur. Ramazan ayında dışarıda sigara içtiği için oğluna kızan Süryani bir baba ile evine gelen Süryani komşusundan özür dileyerek sofradan "et” i kaldıran Müslüman bir babanın davranışları, karşılıklı hürmete güzel bir örnektir. ${ }^{11}$ Bunun dışında zikredilebilecek benzer örnekler de söz konusudur. ${ }^{12}$

\footnotetext{
${ }^{10}$ Süryanilerin Müslümanlarla tanışmaları, onlarla bir arada yaşamaları ve Bizans’a karşı gösterdikleri mukavemete dönük birliktelikleri hakkında geniş bilgi için bkz. (Akyüz, 2006; Azimli, 2005).

"Süryaniler, tuttukları büyük oruçta "et” yemezler. Bu nedenle et, sofradan kaldırıır.

${ }^{12}$ Farklı örnek biçimleri için ayrıca bkz. (Ağırakça, 2009: 41-43; Bulaç, 2009: 146-147).
} 
Süryaniler ile Müslümanların, etkileşim bağlamına ve seviyesine bağlı olarak birbirlerine kiriv(kirve) dedikleri de yakın zamana kadar bilinen bir durumdur. Süryanilerle konuşulduğunda "Allahımız bir, tek bir Allah vardır." sözünü duymak her zaman olasıdır. Kilise, cami ve mezarlıklar merkezinde dinî sınırların olduğu vakidir, fakat bu sınırlar, hem komşuluk hem de çarşı-pazardaki sürdürülebilir nitelikteki etkileşimlere engel olmamaktadır.

Bölgede konuşulan Süryanice, Arapça ve Kürtçe dillerinin birbirinden alışveriş yapması da belirtilen etkileşimler sebebiyledir. Bahsedilen örnek etkileşim biçimleri, ufukların kaynaşması yaklaşımını da örneklemektedir. Hakkari Keldanilerinden Aziz Yalap'ın belirttiği gibi; köylüler ile olan tartışmalar, dinden ziyade arazi sınırları sebebiyle olmuştur (Yalap, 2011: 90). Bazı sosyal meselelerin imam ve papaz eşliğinde çözüme kavuşturulmaya çalışılması da konuyu örneklemesi açısından önemlidir (Yalap, 2011: 78). ${ }^{13}$

Verilen örnekler, ebrulî kültür içindeki farklı etnik ve dinî grupların, aşağıda açıklanacağı üzere, birbirlerine değen olarak nasıl değer atfettikleri ve değerken aynı zamanda birbirlerini değerlendirdikleri/yorumladıkları ve değer standartlarını da ona göre belirledikleri ile ilgilidir.

Ebrulî kültürün değere bağlı olarak değişmeye veya etnisizm mesafesine gelmeye açık olduğunu da göz önünde bulundurmak gerekir. Yaşanmış tecrübelerde bunun örneğini görmek mümkündür: 1915'te kendini gösteren Süryanilere dönük girişimler, herkesçe bilinmektedir. Bilinen bir gerçek daha var ki, o da bölgede kabul gören karizmatik Şeyh Hamid'in torunlarından olan Şeyh Fethullah Efendi'nin bu yıkıcı girişimlere engel olmak için gösterdiği gayretlerdir. Şeyh Fethullah'ın bu yöndeki uğraşları da ebrulî kültürün kendi dinamikleri içinde açıklanabilecek bir husustur.

Şeyh Fethullah, Mardin'in Midyat ilçesine bağlı Gülgöze (Aynverd) köyünde üç ay süren çatışmaları engellemek için kendi yeğenini -diğer bir görüşe göre kendi oğlunu- Süryanilerin güvenini kazanmak adına rehin bırakmıştır. Bununla birlikte Süryanilerin canlarının, mallarının ve ırzlarının haram olduğu fetvasını da vermiştir (Omay ve Dinç, 2009: 83). Bu girişimlerin neticesinde tarafların sakinleşebilmesi ve olayların olumlu yönde neticelenmesinin temel sebeplerinden biri, vaat edilen güvenli ortamın tarihî süreç içerisinde yani yaşanmışlık içinde bir karşılı̆̆ı/değeri olmasından kaynaklanmaktadır.

Şu da belirtilmelidir ki, o dönemde yaşanan sosyo-politik çatışmalara sebep olan kriz, aynı zamanda değer krizidir. Buna rağmen içsellik kazanan kolektif değer ufku, kriz zamanında tarafları kendinde tutmaya güç yetirebilmiştir. Bu yöndeki değer, lokal krizlere indirgenmemelidir. Belirtilen ortak ufkun Türkiye için geçerli olduğunu, hatta Türkiye'nin sınırlarını da aştığını söylemek mümkündür.

\footnotetext{
${ }^{13}$ Aziz Yalap’tan aktarılan örnekler, benzer etkileşimlerin farklı bölgelerde de geçerli olduğunu vurgulamak içindir.
} 
Bahsedilen örnek etkileşim biçimleri mozaik, melez ve gökkuşağı kelimeleri üzerinden tanımlanamayacak kadar yaşanmışlık tecrübesini içinde barındırmaktadır. Ebrulî kültür kavramı, tarihî süreçte birikerek gelen farklı etnik ve dinî gruplar arasındaki yaşanmışlığın iç dinamiklerini vurgulamakta ve bu yöndeki hassasiyetleri de imlemektedir.

\section{Yeni Bir Kavram Olarak Ebrulî Kültür}

Teknik anlamda ebru, kendine has yöntemlerle yoğunlaştırılmış su yüzeyine serpilen çeşitli doğal boyalarla elde edilen desenlerin suyun üstüne kapatılan kağıda aktarılmasıyla yapılan bir süsleme sanatıdır. Farklı dillerde bulut, bulutumsu, su yüzü, damarlı, dalgalı anlamlarına gelen ebru ifadesi ebri, abru gibi isimlerle anılmış olmasına rağmen günümüzde ebru olarak zikredilmektedir. (Barutçigil, 2010: 7). ${ }^{14}$ Sıfat olarak kullanıldığında "üzerinde farklı renkler bulunan" anlamında ebrulî ifadesi kullanılmaktadır. Kavramsallaştırma çerçevesinde vurgulanan kullanım, özellikle ebrulîdir. Farklı grupların diğerine değen karşılıklara sahip olarak konumlandıkları zemin de ebrulîdeki su olmaktadır. Başka bir ifadeyle, gruplar arası etkileşimleri vurgulamak için ebrulî kültür denilirken durgun, değișmeyen, kapalı ve yalıtılmış bir alandan bahsedilmemektedir. Ebrulî kültür, hem değișimi hem de değer merkezli olmak üzere diğerlerinin kendinden değerini/anlamını ve karşılıklı değerlendirmelerini kendi içinde barındırmaktadır. Buradaki yapıyı kendi inşa süreciyle özdeş olarak değerlendirmek mümkündür.

Alegorik bir biçimde ebrulî, renklerin su zemininde konumlanarak birbirine değmesi, renklerin kimi durumlarda değişmesi veya -değișmemiş (!) olsa bilerenginin kendine özgül olması (özgül, çünkü ebrulîdeki bir renk, en azından, diğerlerinden yansımalar aldığı için her haliyle özgüldür) durumu, farklı etnik grupların karşılıklı etkileşimlerine ve değişim durumlarına gönderme yapmaktadır. Ebrulî ifadesi, tüm bu etkileşimleri ve konumlanmaları örneklemesi açısından bir metafor olarak da değerlendirilebilir. Bu itibarla hiçbir renk diğerinden ayrı olarak düşünülemez. Her bir renk diğeriyle beraber varlığını sürdürür. Ortak zemin, bir rengi -değişmiş halleriyle de olsa- özgül kılar. En yalıtılmış haliyle, diğer renklere değmemiş(!) ve değişmemiş(!) olsa bile mavi, ortak zeminin dışında duran mavi gibi değildir: Ebrulî’nin mavisidir.

Ebrulî ifadesi, sadece renklerin birbirine dönük konumlanmalarını değil, tüm bu etkileşimlerle beraber, uzun tarihî geçmişe dayanan kuşatıcı ufuk bütünlüğüne ve ortak zemine de işaret etmektedir: Sadece renk(ler) değil, içinde konumlandıkları su ile birlikte ebrulî. Başka bir ifadeyle, bu ortak alanda yaşayan

\footnotetext{
${ }^{14}$ Sözcüğün aslen Orta Asya dillerinden Çağatayca'daki ebre (damarlı, dalgalı) kelimesinden geldiği kabul edilir. Bu sanat, İran'da yaygınlaşmasıyla birlikte "bulut gibi”, "bulutumsu” anlamlarına gelen ebri veya Farsça bir kelime olan abru (su yüzü) sözcüğü ile anııı. İslam sanatları arasında da önemli bir yeri olan ebru sanatının ilk nerede ortaya çıktı̆̆ı kesin olmamakla birlikte yaygın kanaatin Çin, Türkistan veya Hindistan olduğudur. Fransızlar, desenlerin mermere benzeyen damarlarından dolayı ebruya "papier marbre", ingilizler de "marbled paper" adın verirlerken, Araplar da damarlı kâğıt anlamına gelen "varak'ül-mücezza” sözcüğünü kullanmaktadır. Geniş bilgi için bkz. (Barutçugil, 2010: 7).
} 
Süryaniler, Hindistan'da yaşayan Süryaniler gibi değildir. Belirtilen özgül konum Müslümanlar veya Araplar ve Kürtler için de geçerlidir.

Ebrulî kültürdeki etkileşimlerin dinamiklerini değer yaklaşımı ile açıklamak mümkündür. Değer yaklaşımı, farklı etnik ve dinî grupların -tarihi kökenlerini yadsımadan- karşılaşmalarına, temas etmelerine, alış-verişlerine, sınırlarına ve sınırlarının geçişken durumuna içkin olarak kullanılmaktadır. Makale içindeki değerlendirmelerde değer kavramının kullanımında bir yoğunluğun göze çarpması, kavramın bu doğal özelliğinden kaynaklanmaktadır.

Değer olgusu; genellikle iyi, uygun, arzu edilir davranışlar/anlayışlar, harcanılan enerjiyle ölçülen eşya/nesne ve mal üretimi merkezindeki etkileşimlere işaret eden mübadele ve eylem perspektifinden ele alınmaktadır. Yapısal çerçevede ise "anlamlı farklılık" (üst anlam bütünlüğü içerisinde karşılıklı öznelerin içinde bulunduğu konum) yaklaşımıyla öne çıkmaktadır (Graeber, 2015: 18). Bu noktada şunu belirtmek gerekir ki, "fark"lı olma durumu, bizzat değer(li) değildir; farklılığı belirleyen husus anlam bağlamındaki değerdir. Bu çerçevede değer, anlam ile ilişkili bir durumdur. Fark ise değerin ve önemin başkasının gözünde var olmasıyla alakalıdır. Bu açıdan temel değer(ler), karşılaşma ve temas yoluyla diğer toplumların varlığından haberdar olunduğunda tanım kazanır. Ayırt edici unsurlar, teması ve ek olarak -etkileşim temeli için- ortak paylaştıkları bir konunun -ki bu değer ve anlam alanıdır- olmasını zorunlu kılmaktadır (Graeber, 2015: Bölüm 2).

Bir terimin sistem (dil) bütünlüğü içindeki yerine göre anlam kazanması gibi eylem(ler) de aktör açısından daha büyük toplumsal bir bütünlüğe dahil edilerek anlamlı hale gelebilmektedir. Başka bir ifadeyle değer, aynı zamanda daha geniş bir kavramsal kategori içindeki tanımlamayla da ilgilidir. Dolayısıyla daha derin ve daha kuşatıcı olan alan/anlam daha değerli olabilmektedir (Graeber, 2015: Bölüm 1).

Değer kavramı, hem anlam hem de ahlak ve parasal olarak biçilen kıymet gibi hususların hepsine işaret edebilmektedir. Kavramın muğlâk gibi görünen bu özelliğini şu şekilde açıklığa kavuşturmak mümkündür: "Değer” kelimesi, yapılan işe karşılık gelmesi (karşılık olma) ya da karşılık gelmemesi anlamında dile getirilen "değmek” kökünden türemiştir. Bir şeyin bir şeye "değme’si”, birinin diğerine karşılık gelmesi anlamındadır. Bununla birlikte değer kelimesi; “paha”, "kıymet" anlamına da gelmektedir. Paha ve kıymet anlamındaki değer kelimesi ile "karşılık gelmek”, “temas etmek”, “dokunmak” anlamına gelen değmek kelimesi aynı kökten doğan ve anlamsal ilişkileri olan kelimelerdir. Dolayısıyla değer kavramının hem maddi karşıı̆̆ı anlamında, hem dokunmak, temas etmek anlamında hem kıymetine karşılık olarak kullanılması hem de kavramlar düzeyinde karşılık olarak kullanılması mümkündür (Göktaş, 2016: 48-49).

Eylemin ve nesnenin toplumsal ilişkiler bağlamında tanınmış bir alana karşılık gelmesi/değer olması/değmesi, eylemi kabul edilebilir kılarken; aktörün 
yaptığı eylemle içinde bulunduğu konumdan tanınmış daha büyük bir toplumsal alana dahil olması ise o eylemi anlamlı kılmaktadır. Bu itibarla gruplar arası etkileşimler açısından değer, anlamla da içkin bir şekilde, eylem/değmek/etkileşim/karşılaşma yoluyla ortaya çıkmaktadır.

“Değmek” eylemi, karşılıklı iki şeyin birbirine değmesi veya karşılaması durumunda "değişmek" (değişim ve mübadele) durumunu da beraberinde getirmektedir. Bu durumda iki şey birbirini eksiksiz olarak karşılıyorsa - hem değişim hem de mübadele anlamında- değişme(k) kaçınılmaz bir hal alır. Dolayısıyla, her iki tarafı da değer olan (diğer/i: aynı değerde olan) bir eylem, istikrarlı biçimde söz konusuysa değişme/k de gerçekleşir. "Eğer bir yerde bir değer varsa, onun değebileceği, onun karşılayabileceği bir başka şey de olmak durumundadır. Aksi takdirde değer, değerini ne kadar korursa korusun karşılık geldiği bir şeyi yoksa onun değerinin bilinmesi beklenemez." (Göktaş, 2016: 4951).

“Değer” ile ilgili yapılan değerlendirmelerin -karşılaşma, eylem, etkileşim bağlamında- hem kültürün oluşumu hem devamı hem de değişimi ile ilişkisi açıktır. Kültür, karşılıklı etkileşimler/karşılaşmalar yoluyla kurulurken hem tarihî köklerinden getirdiği veya kendi içinde taşıdığı anlam(lar)ı değerler yoluyla kurumsallaştırıp derecelendiriyor hem de diğerleriyle kendi değeri üzerinden değerken değişebiliyor. ${ }^{15}$ Bu açıdan bakıldığında farklı etnik kimlikler arasındaki etkileşimleri farklılıklara indirgemek, grubun kendi içindeki kendine dönük pahasını arttırıyor fakat grup dışı etkileşimlerde onu değersiz hale getirebiliyor; karşı tarafı değer olmaktan çıkartıyor ve önemsizleştiriyor. ${ }^{16}$ Bu noktada ötekileştirme sorunsalı, değersizleştirme yoluyla kendini gösteriyor. ${ }^{17}$ Ebrulî kültür ise hem değer alanı açmaktadır hem de kimliği, "kıymeti kendinden” (kök yapı ile birlikte anlamlı farklılık) bir özne olarak kabul etmektedir. ${ }^{18}$ Kıymeti kendinden vurgusu, tarihî köklere işaret etmekle birlikte literatürde kullanılan kültürün "değer standartları", "değer yargıları" ve "anlam sistemleri” ile de doğrudan ilişkilidir.

Değer, değmek, diğer ve değişmek zeminindeki bu yaklaşım, ebrulî kültürün değerini, aynı zamanda diğerine (değerine/öz-saygı) hak ettiği kadar değer vermek (eleştirel sorumluluk) temelindeki etkileşimleri ve ortak yaşam ufkunun/alanının neye göre kuşatıcı olduğunu vurgulamaktadır.

Etkileşimlerin sürdürülebilirliğini açıklamak, daha doğrusu birbirinden farklı ama aynı zemindeki değerli konumlanmaları açıklamak için "diyakritik

\footnotetext{
${ }^{15}$ Bu makalede karşılaşma (ve aynı zamanda uyarılma) olgusu, doğumla başlayan ilk andan itibaren birinin evren, coğrafya, insan gibi unsurlarla karşılaşması, tanışması, konum alması sürecini de içerecek şekilde kullanılmaktadır.

${ }^{16}$ Bir varlı̆̆ı veya nesneyi "yerli yerinde kullanmamak/değerlendirmemek" ve "gereğinden az değer vermek", "zulüm” kavramıyla eşdeğer bir durumdur. Dolayısıyla ötekileştirme sorununu aşabilmek, sağlıklı bir ontolojik anlamlandırmayı da gerektirmektedir.

${ }^{17}$ Bu açıdan "ötekileştirme" kavramının da sorunlu bir kullanım olduğu söylenebilir. Bunun üzerinden tartışılan sorunsal konumlanmaların "değer” merkezli yorumlanması gerekir.

18 “Kıymeti kendinden” vurgusu için ayrıca bkz. (Göktaş, 2016: 49).
} 
yorumbilgisi" yaklaşımı önemli ipuçları sunmaktadır. Bu yaklaşım biçiminde diğerleriyle aynılığa düșmemek kadar kendini nüfuz edilemez bir başkalık konumunda tutmamak da esastır. Burada ahlaki etkileşimler ön plandadır. Karşılaşmadan sonraki etkileşimleri eleştirel sorumluluk üzerinden sürdürülebilir kılmak ya da bunun derecesini belirlemek ön plandadır. Diğeri ne mutlak anlamda yabancı ne de mutlak anlamda aşinadır. Diğerini fazla aşkın veya yabancı kabul etmek değerli etkileşimleri ortadan kaldırırken, fazla aşina ve yakın kabul etmek de ahlaki mesafeyi kaybettirir. Bu yönüyle asgari özsaygı da ahlakiliğin olmazsa olmazıdır (Kearney, 2012: 24). Başka bir ifadeyle diğerinin karşısında iki biçimde durulur: Biri "başkası olarak kendisi” (özne), ikincisi ise "diğerinin bir başka benlik olarak tanınması” (özne) biçimindedir (Kearney, 2012: 104-105). Kendi benlik değerinden değdiği kişinin değerini bilmek söz konusu olduğu gibi diğerini mutlak anlamda aşina olarak kuşatılmış veya bizce kontrol edilebilecek uzantımız olarak görmemek de söz konusudur. Her biri “diğer bir değer”lidir. Sınırları bilmek ve sınırları karşılıklı kollamak, etkileşimlerin devamı açısından vazgeçilmezdir. Mahremiyetler korunur, fakat bu birbirine "misafir" olmaya engel değildir. ${ }^{19}$ Ahlakiliğin asgari düzeyde kendine ve diğerlerine karşı güveni (güvenlik) ve öz-saygıyı gerektirdiği, aksi takdirde sosyal ilişkilerin zaten sürdürülemeyeceği göz önünde bulundurulduğunda, bu yöndeki konumlanmanın kimlik sorununu da barındırmadığı söylenebilir. Çünkü bu konumlanmada var olan asgari öz-saygı, güven ve değer, kimliğin işlevselliğini de yerine getirebilmektedir (Hortaçsu, 2007: 16-17). Bu açıdan ebrulî kültür, birey ve gruba dönük kimliksel sorunların aşılmasında önemli bir alan açmaktadır.

\section{Temel Özellikleri İtibariyle Ebrulî Kültür}

Ebrulî kültür, kısa vadeli politik stratejiler ve ideolojik kamplaşmalar merkezinde oluşmamıştır. Bu çerçevede ebrulî kültürün uzun tarihi geçmişine ve bazı özelliklerine değinilmelidir.

\section{a. Ebrulî Kültür Uzun Tarihi Geçmişe İşaret Etmektedir}

Ebrulî kültürdeki etkileşimlerin uzun tarihî geçmişe dayanmasında İslam fetihlerinin önemli bir yeri vardır. Aynı zamanda antik çağdan günümüze uzanan bölgenin (Mardin ve çevresinin) tarihî sürecinde Aramiler, Asurlar, Persler, Yunanlılar, Romalılar, Araplar, Kürtler ve Türkler önemli roller oynamışlardır.

İslam fetihlerinden hemen önceki süreçte bölgede Roma ve Fars imparatorluğunun etkisi söz konusudur (El-Batâyine, 2000: 870-871). Bu iki imparatorluğun stratejileri ve hâkimiyet savaşları, Süryaniler başta olmak üzere yaşamı uzun yıllar olumsuz etkilemiştir. Öyle ki Süryaniler, VII. yüzyılda başlayan İslam fetihlerini sevinçle karşılamış, hatta desteklemişlerdir. Halife Ömer'in, ehl-i kitaptan olan gayrimüslimlere dönük zimmî statüsünü tanımlayan fermanı da uzun tarihî süreçte esas alınmıştır. ${ }^{20}$ Antlaşma (ahitname) içeriği itibariyle zimmî

\footnotetext{
19 Ayrica bkz. (Kearney, 2012: 32-33;92).

20 İslam dininin zimmîlere dönük yaklaşımının genel bir değerlendirmesi için bkz. (Karlığa, 2009; Ağırakça, 2009).
} 
statüsünde olan gayrimüslimlerin canı, malı, namusu haram kılınmış, dinleri ile birlikte koruma altına alınmış ve Müslümanların emaneti olarak ilan edilmiştir (Şer, 2002: 372-385). Bu süreçte derin ve kuşatıcı olan anlama dönük değerin -ki tarafların mülkiyet konusu yapılamaz- temelleri atılmıştır. Yapılan antlaşmanın sosyo-kültürel alandaki etkisi asırlarca devam etmiştir. Kaldı ki XX. yüzyılda bile Şeyh Fethullah Efendi'nin aynı gerekçelerle krizi aşabilmesi dikkat çekicidir. Bu krizin aşılmasında uzun yıllara dayanan dinamikler ve/veya “değer”ler etkili olmuştur.

İslam fetihlerinden sonraki süreçte Süryaniler, Selçuklu ve Artuklularla da iyi ilişkiler kurmuşlardır. Osmanlılarla olan ilişkileri ise XIX. ve XX. yüzyıllarda inişli çıkışlı olmuştur (Akyüz, 2009: 63-73). ${ }^{21}$ Çok yönlü etkenlerin sebep olduğu en temel krizler, bu dönemde kendini göstermiştir.

Osmanlı, farklı dinî gruplara dönük zımmî ve millet sistemini icra etmişti. ${ }^{22}$ Gayrimüslimler, zimmî statüsünde değerlendirilerek kendi geleneklerini yaşamada serbest bırakılmışlardı (Seyfeli, 2005: 264). Sistem, sadece belli bir coğrafyada yaşayanları değil, dağınık yerleşme biçimi gösteren grupların da dinî kimliklerini güvenceye almıştı (Ortaylı, 2001: 19). Shaw'ın tespitiyle, “Osmanlılar, dünya tarihi boyunca başka yerlerde başka istilacıların yaptıkları gibi yaşayanları din değiştirmeleri için zorlamayı reddetmemiş olsalardı, Osmanlı İmparatorluğu'nu son yüzyılda büyük zaafa düşürecek hiçbir azınlık sorunu da olmayacaktı." (Shaw, 1985: 1003).

Osmanlı millet sisteminin, Müslüman tebaa azınlıkta da olsa, diğer dinleri (ve toplumları) de kapsayacak şekilde can ve din selametini, din güvenliğini, selamı ve karşılıklı güveni yayarak istikrar ve nizamı tesis etme ilkesini esas aldığını söylemek mümkündür. Nitekim XVI. yüzyıla kadar Osmanlı'da Müslüman tebaa azınlık konumundaydı (Soykan, 2005: 2). Bununla birlikte şu da belirtilmelidir ki sistem, modern azınlık anlayışının çatışmalı konumlanmasının aksine güvenlik esasına dayanıyordu (Özcoşar, 2005: 214).

Günümüz itibariyle Türkiye, Osmanlı'nın sosyo-kültürel mirasından izler taşımaktadır. Ebrulî kültür, genel hatlarıyla yukarıda belirtilen asırlarca uygulanmış istikrar ve nizam esaslı millet teşkilatlanmasının etkilerini ve izlerini barındırmaktadır. Buna ek olarak farklı etnik ve dinî grupların sosyo-kültürel alanda kendilerine has konumlanmalarıyla bir değer alanı oluşturduklarını da belirtmek gerekir.

\section{b. Ebrulî Kültürde Sürdürülebilir Etkileșimler Esastır}

Ebrulî kültürdeki etkileșimlerin sürdürülebilir olması, diğerinin özne (öznenesne değil; özne-özne konumlanması) konumunda değerlendirilmesiyle

\footnotetext{
${ }^{21}$ Ayrıca Süryanilerin Araplarla tanışmaları, Müslümanlarla bir arada yaşamaları ve Bizans’a karşı gösterdikleri mukavemete dönük birliktelikleri hakkında geniş bilgi için bkz. (Akyüz, 2006; Azimli, 2005).

${ }^{22}$ Illgili araştırmasında Seyfeli (2005), Tanzimat öncesi dönemi zimmîlik, sonrasını ise millet sistemi içerisinde değerlendirerek böyle bir ayııımla konunun daha anlaşııı olacağını belirtmektedir.
} 
gerçekleşebilmektedir. Birinin diğerine sınırları dayatmasından ziyade, sınırın gerektirdiği hassasiyetlere göre konum alması söz konusudur ve buna kendi değer(ler)i ölçüsünde riayet edilir. Yaşanmışlığa dair verilen örnekler bunun bir göstergesidir.

Farklılıklar ve sınırlar gökkuşağı konumlanmasında olduğu gibi değildir. Yukarıda da belirtildiği gibi gökkuşağı modelinde şöyle bir tablo vardır: Tarafların oruç zamanlarında biri, diğerinin hassasiyetini gözetmeden serbest davranabilir. Yani Ramazan ayının oruç vaktinde bir Müslümanın karşısında yiyecek yemek ve Müslümanın "buna saygılıyım"(!) demesi ya da büyük oruçta Süryani birinin yanında et yemek ve Süryani olanın bunu saygıyla(!) karşılaması durumu söz konusudur. Gökkuşağında tahammül gerektiren bir durum varken, ebrulî kültürde içsel/kuşatıcı, kabul gören bir fedakarlık/diğergamlık ve hürmet söz konusudur. Bu açıdan günümüzde Mardin'in ve Türkiye'nin gökkuşağı konumlanmasına doğru evrildiği söylenebilir.

Ebrulî kültür, süreç içerisinde karşılaştığı problemlere çözümler üreterek günümüze kadar gelebilmiştir. Mesela, etnisizmin dil merkezli dışlama-dâhil etme sorunsalı, "bir dil, bir insandır"; iki dil bilmek, iki insan ufkudur yaklaşımıyla aşılabilmiştir. Böylece diğerlerinin etnik diline karşı konumlanmada bilinçli bir sınırlamanın veya mesafenin ötesinde öğrenmeye açık bir alan açmıştır. Etnisizmde olduğu gibi etnik dil üzerinden dış-grubun/diğerinin yabancı olmasına izin verilmez.

Diğer dilleri de akıcı konuşabilmek, özellikle ticaret ehli insanlarda kendini gösteren bir durumdur. Bu noktada ebrulî kültür, "dil”e değer üzerinden yaklaşım sergilemektedir; yaşam pratiklerini kolaylaştıracak bir imkan sunarak öğreneni de kıymetli hale getirmektedir. Ebrulî kültürde dil öğrenimi, zenginliğe (maddi-manevi) ve samimi etkileşimlere kaynaklık etmektedir. Bundan hareketle şu söylenebilir: Bir yerde dilin öğrenilmesi isteniyorsa değerli seçenek imkanlarının da verilmesi ve ebrulî kültürde olduğu gibi hem kıymet hem de değen olarak değerinin ortaya konması ve hatta bu değerin yükseltilmesi gerekmektedir.

Ebrulî kültürde oluşan krizler şeyh, imam, papaz, metropolit, muhtar, belediye başkanları ve karizmatik liderler gibi bilirkişiler yoluyla aşılmaya çalışılır. Krizde ısrarcı olmak, temel konumlanma biçimi değildir, aksi takdirde telafi edilemeyecek sonuçlar ortaya çıkacaktır ve bu durum taraflarca da bilinir. Daha büyük/kuşatıcı olan toplumsal alanın/üst değerin yitimi, krizin sürekliliğini de beraberinde getirecektir. Tam da Graeber'in (2015: 377-378) benzer bir şekilde belirttiği gibi üst değer alanı -Graeber'e göre hayali bütünlükler- yerinden edilmişçesine gözden kaybolduğunda bile yeniden ortaya çıkma eğilimindedir. Bu değeri temsil eden bir aktör veya bir sembol, krizlerin aşılmasına aracılık edebilir. Tüm bunlarla birlikte şu da belirtilmelidir ki, belirtilen çerçevede ebrulî kültürün değer bağlamının kuşatıcılığı günümüz itibariyle azalmaktadır. 


\section{c. Ebrulî Kültürdeki Stereotiplerin Genel Değeri Yoktur}

Stereotip denilen kalıp yargılar, bir grubun kültürel bilgisinin bir parçası haline gelerek etkileşimleri yönlendirebilen yargılardır (Eriksen, 2004: 41-42). Bu yargılar, çevreyi basitleştirerek tanımlaması yönüyle işlevseldir ve aynı zamanda güncel yaşamın bir parçasıdır (Bilgin, 2007: 120).

Sosyo-kültürel yaklaşım itibariyle stereotiplerin temeli kültürel çevredir. Bireyler, sosyalleşme sürecinde öğrendikleri stereotipler üzerinden etkileşim sergileyebilirler. Kişilerin kalıp yargıları benimseme düzeyleri birbirinden farklıdır (Yapıcı, 2004: 38-41). Bu nedenle stereotipler, her zaman için insanların gerçekte ne şekilde davrandıklarını iyi açıklamazlar. Çünkü bu yargılar, hem zamanla gerçekliğini kaybedebilir hem de yapıları gereği mutlak gerçek olmak zorunda değildir (Eriksen, 2004: 42; Yapıcı, 2004: 11).

Farklı etnik ve dinî gruplar arasında da stereotipler söz konusudur ve görece etkileşimlerden kaynaklanmaktadır. Etkileşimler, sınırları keskinleştiren etnik ve dinî konumlanma biçiminden ziyade kendi değerlendirme biçiminden hareketle -ki bu, aynı zamanda bilinç seviyesiyle ilgilidir- diğerine ya da kendi değerine hak ettiği kadar değer vermek esasına dayanmaktadır. ${ }^{23}$ Sorun, olumsuz yargılar üzerinden aşırı genellemeler yoluyla tutumlar sergilemektir (Berry vd., 2015: 351). Mevcut kalıp yargılarını "Aslında bunlar (farklı etnik ve dinî gruplar) anlayış ortamında yaşamıyorlar, kendi içlerinde önyargıları var." şeklinde formüle etmek gereksizdir. Ebrulî kültürün tecrübî kuşatıcılı̆̆ı, etkileşimleri krizlere indirgemeye engeldir. Değersel krizlerin aşılması, ancak karşılıklı biçimde anlamlı farklılık kategorisindeki değerin korunması ile mümkündür.

Farklılıklar arasındaki etkileşimlerin yoğunluğu kalıp yargıların sürekliliğini de belirlemektedir. ${ }^{24}$ Yoğun etkileşimler komşuluk, akrabalık, ticari alışverişler ve dostluk gibi yakınlıklar üzerinden söz konusu olabilmektedir. Komşuluk gibi yakın mesafeden tanışma, genelleştirilmiş olumsuz yargıların dışına çıkmaya da alan açabilmektedir. Bu alan büyüklüğüne bağlı olarak krizlerin aşıımasına da aracılık etmektedir.

\section{d. Ebrulî Kültürde Değișim Değerseldir, Krizler Değer Kaybıdır}

Farklı etnik ve dinî gruplar arası etkileșimler bağlamındaki değișim olgusu, değer bağlamının dönüşümü ile ilgilidir. ${ }^{25}$ Farklılıklar arasındaki temas, konularına

\footnotetext{
${ }^{23}$ Bölgede yaşayan Hıristiyan Süryanilerin, Müslüman Kürt ve Arapların birbirine dönük bazı kalıp yargı, olumsuz tutum örnekleri ve ilgili değerlendirmeler için bkz. (Özmen, 2006:226-234; Sarı, 2010: 322-334). Özellikle olumsuz yargı ve tutumların, ekonomik, politik ve güncel menfaatler sebebiyle krizleri destekleyebileceğini söylemek mümkündür.

${ }^{24}$ Temas kuramına göre kültürler arası temas ile olumsuz yargıların azalması arasında doğru orantı söz konusudur. Bu durum, bazı ortak amaçları paylaşma, belirli düzeyde işbirliği gibi koşulların yokluğunda bile söz konusu olabilmektedir (Berry vd., 2015: 347-346). Ebrulî kültür, açıklanan bağlamda, farklı gruplara bu alanı açmaktadır.

${ }^{25}$ Sosyal bilimlerde değişim olgusu, modernleşme sürecine eşdeğer ele alınmakla birlikte ilgili yaklaşımlar, genellikle büyük, orta ve küçük boy kuramlar ile hızlı-yavaş, radikal-yumuşak, iradî (planlı)-gayr-i iradî (plansız) değişimler olarak tasnif edilebilmektedir. Kültürün öğeleri açısından maddi ve manevi değişimlerin kıyaslaması da yapılmaktadır. Bununla birlikte değişim, modernleşme süreci itibariyle "geleneği red" süreci olarak da söz konusu
} 
bağlı olarak kültürel alışverişler hususunu ifade etmektedir. Burada değişim, kavramsallaştırmada bahsedilen değmek, diğer ve değer olgularıyla içkin olarak ele alınmaktadır.

Ebrulî kültürdeki farklı etnik ve dinî gruplar, hem etno-kültürel açıdan hem de din itibariyle birbirinden etkilenirler. Karşılıklı alışverişler, özellikle konu yakınlığının olduğu alanlarda söz konusudur. Bu durum gündelik hayatta kullanılan dilde de kendini göstermektedir: Kürtler, Süryaniler ve Araplar birbirlerinden alışveriş yaptıkları için birçok kelimeyi ortak biçimde kullanılabilmektedir. Bu anlamda dillerin saf olmadığını ve fasih dilden farklıık arz ettikleri söylenebilir. Dillerin saf olmaması, farklı grupların uzun tarihi süreçteki yoğun etkileşimlerinin bir göstergesidir.

Birikerek günümüze kadar gelebilen ortak ufkun/tecrübenin yeni kimliklenmeler yoluyla tek bir unsura/gruba indirgenme riski de söz konusudur (Özcoşar, 2009: 105). Buradaki değersel zenginliğin sadece Kürtlere, sadece Araplara veya sadece Süryanilere ait görülmesi değersizleştirme sorununu da beraberinde getirecektir. Günümüz itibariyle bu değerin modernleşme ve küreselleşme olguları gibi çeşitli sebeplerle gökkuşağına doğru dönüşerek zayıflamaya doğru gittiği söylenmelidir.

Gökkuşağı konumlanmasındaki etkileşimler, eleştirel sorumluluk yakınlığında değildir, süreklilik de arz etmezler. Buradaki etkileşimler geçiciliğe ayarlıyken, ebrulî kültürde ise sürekli biçimde varlığı diğerleriyle beraber sürdürülen bir alan ve yakınlık söz konusudur. Başka bir ifadeyle değer, idealize biçimde üzerinde konuşulan değil, içinde yer alınan bir konumlanma gerektirir. Bu yönüyle değer kaybının olduğu krizler de söz konusudur.

Değer krizinin tezahürlerinden biri, pratik yaşamı parçalayan retoriktir. Siyasi-politik (dikey) ve sosyo-kültürel (yatay) alan itibariyle "değerin ne olduğunu belirleme mücadelesi” kendini gösterebilir (Graeber, 2015: 143; Eriksen ve Nielsen, 2014: 219). Etnopolitik süreçlerde olduğu gibi yatay ve dikey düzlem arasındaki çatışmalar karşılıklı retorik üretirken, tarihî geçmişi olan gündelik yaşamdaki değer ise davranış üretecektir. Sosyo-kültürel zeminin kayganlığı arttıkça değersel davranışlar da yerini retoriğe bağlı edimlere ve krizlere bırakacaktır.

Ebrulî kültürdeki değer kaybı, tarihî süreçte birikerek oluşan ufuk bütünlüğüne kıyasla söz konusudur. Daha önce bahsedilen bir Süryani ile bir Müslüman babanın davranışları, kolektif düzeyde hem tanınmış bir alana karşılık gelmektedir hem de daha büyük bir toplumsal alanda/anlamda konumlanmaktadır. Tersi durumda ise krizler vuku bulabilmektedir. Değer kaybı, krizin taraflarından biri veya her biri için söz konusu olabilir. Ebrulî kültürde krizler çıkabilir, fakat mevzu bahis olan husus ebrulî kültürün krizleri aşma tecrübesidir. 
Krizler süreklilik göstermeye başladığında ebrulî kültürden bahsetmek de zorlaşacaktır.

Yukarıda işaret edilmeye çalışılan ebrulî kültürün temel özelliklerine şunlar da ilave edilebilir:

Ebrulî kültürde yaşayan farklı etnik ve dinî gruplar arasında kültürel alışverişler (kültürleșme) olduğu gibi dinî senkretik (bir inanç pratiğinin farklı bir dinin unsurlarını barındırarak yeni bir form kazanması) pratikler de söz konusudur. Varlığını günümüze kadar devam ettiren bu unsurlar, istikrar ve huzur dönemlerine bağlı olarak gelişebilmektedir, çünkü böyle dönemlerde sınırlarda esneklik ve etkileşim daha fazladır (Su, 2009: 197; Güvenç, 1994: 126).

Ebrulî kültürdeki etnik kimlik tanımlamaları, çapraz kategorizasyonlar biçiminde kendini gösterebilmektedir. Bu durum, özellikle Müslümanlar için geçerlidir. Köken gözetilmeden, kendini hem Kürt hem de Arap olarak ifade eden tanımlama biçimleri olabilmektedir. Bu yönüyle ebrulî kültür, etnisizmi barındırmamaktadır. Bununla birlikte, etnomerkezcilik (dışarıdakilere engel olmaktan çok kendi grubuna dönük aidiyet bilinci) tanımlamaları da söz konusudur. Fakat bu, ebrulî kültürün etnisizme giden dinamikleri barındırdığını söylemeye engel değildir.

Tüm bu açıklamalara ek olarak şunu söylemek mümkündür: Ebrulî kültür, 94 kendi birliğindeki ben(grup) ve diğer(ler)inin birbirlerine dönük öznesel/değersel konumlarına olduğu gibi öznelerin içinde bulunduğu daha kuşatıcı (bir bütün olarak ebrulî) olan varlık alanına da işaret etmektedir. Varoluş içindeki yer(imiz)e: “Ben'in kendini varlıkla beraber tanımaya çalışması, hatta kendinden önce varlığın ne olduğu konusunda açık seçik bir fikre sahip olması gerekir. Varlık, "ben" dâhil her şeyi kuşatıp öncelediğine göre "ben" bilgisine, varlık bilgisinden başlamak gerekir.” (Kalın, 2016: 457). Bu açıdan ebrulî kültürün değerini kaybetmemesi irfân'ı da gerekli kılmaktadır.

\section{Sonuç}

Batı ülkeleri, sosyo-kültürel meselelerine kendi anlam kodlarından yaklaşım sergileyerek çokkültürcülük politikalarını tartışmışlardır. Zamanla bu tartışmalar, Türkiye'de de yükselişe geçmiş, fakat kavram sorunsalı da kendini göstermiştir.

Türkiye, tarihî geçmişi ve sosyal yapısı itibariyle Batı ülkelerinden farklı bir durum arz etmektedir. Dolayısıyla Türkiye'nin sosyo-kültürel durumuna çokkültürlülük, mozaik, melez ve gökkuşağı gibi kavramlarla işaret etmek yeterli değildir, hatta yanıltıcı olabilmektedir. Bu nedenle ebrulî kültür kavramı önerilmiştir.

Ebrulî kültür kavramı karşılaşma, etkileşim ve değişimi, değer merkezli olmak üzere deneyimlemiş farklılıkların, erimeden ve birbirini dışlamadan/yalıtmadan, aynı zamanda özgül sınırlara ve etkileşimlere içkin 
biçimde bir arada yaşama tecrübesine ve bu tecrübeyi kuşatan bir alana işaret etmek üzere kavramsallaştırılmaya çalışılmıştır.

Ebrulî kültürdeki farklı etnik ve dinî grupların (renklerin) çapraz kategorizasyonlar biçimindeki konumlanmaları, diğerine (ve aynı zamanda kendi değerine) hak ettiği kadar değer vermek temelindeki etkileşimler ve sürdürülebilirlik esasıyla günümüze kadar gelebilmiștir.

Ebrulî kültür alanı, küreselleşme sürecinde kendini gösteren yeni kimliklenme stratejileriyle değerini kaybetme riski taşımaktadır. Yeniden icat edilen etnik kimliklenmeler, kavrayıcı ve derin bir şekilde farklılıkları kuşatan ebrulî kültürün etkileșim alanını etnik bileşenlere indirgeme özelliğiyle ön plana çıkabilmektedir. Bu yönüyle dışlama sorunu, değersizleştirme biçiminde kendini göstermektedir.

Etnisizmin barındırdığı, özellikle dil merkezindeki dışlama ve dâhil etme stratejisi yönündeki problemleri elimine eden ebrulî kültür, krizleri çözebilme potansiyeline sahip olmuştur, fakat günümüzde bu potansiyel azalmaya doğru gitmektedir. Makalede bu azalma, tarihî süreçte yaşanmış bazı çatışmalı krizler dışında, gökkuşağı örnekleriyle de vurgulanmıştır: Ebrulî kültüre kıyasla gökkuşağı ve mozaik mesafesi, etkileşimlerin sürekliliğinden ziyade geçici ve nispeten yalıtılmış bir konumlanma biçimi olarak yorumlanmıştır.

Ebrulî kültür, ideolojik konumlanmalardan ziyade yüzyıllardır birikerek günümüze kadar gelebilen yaşanmışlık birikimine dayanmaktadır. Bu kültür, hem gündelik yaşamın inşasında hem de geleceğe dönük sosyal, ekonomik ve siyasi bilimlerin gelişmesinde önemle okunması gereken hassas bir alandır. Dolayısıyla ebruli kültürün kendi içinden ve bağlamına uygun okumalarla araştırılması gerekir.

\section{Kaynakça}

Ağırakça, A. (2009). İslâm Tarihi Boyunca Mardin'de Birlikte Yaşamanın Dini ve Sosyal Boyutları. Türkiye'de Birlikte Yaşama Kültürü ve Mardin Örneği içinde (s.35-43). T.C. Mardin Valiliği.

Akyüz, G. (2006). Süryanilerin Hıristiyan ve Müslüman Araplarla Olan İlişkileri. ì. Özcoşar (Ed.). I. Uluslararası Mardin Tarihi Sempozyumu 26-27-28 Mayıs 2006 içinde (s.527-537). Mardin.

Akyüz, H. G. (2009). Bizanslılar, Selçuklular, Artuklular ve Osmanlılar Döneminde Antakya Süryanî Kadim (Ortodoks) Kilisesi'nin Patriklik Merkezinin ve Süryanîlerin Durumu. Türkiye'de Birlikte Yaşama Kültürü ve Mardin Örneği içinde (s.59-73). T.C. Mardin Valiliği.

Assmann, J. (2001). Kültürel Bellek (A. Tekin, Çev.). İstanbul: Ayrıntı.

Azimli, M. (2005). Müslüman-Süryani İlişkilerine Giriş. A. Taşğın, E. Tanrıverdi ve C. Seyfeli (Yay. haz.). Süryaniler ve Süryanilik içinde (Cilt. I, s. 37-47). Ankara: Orient.

Barutçugil, H. (2010). Ebrulî Mardin. T.C. Mardin Valiliği. 
Berry, J. W., Poortinga, Y.P., Breugelmans, S. M., Chasiotis, A. ve Sam, D. L. (2015). Kültürlerarası Psikoloji (3. bs.). L. P. Tosun (Çeviri Ed.). Ankara: Nobel. Bilgin, N. (2007). Kimlik İnşası. İzmir: Așina Kitaplar.

Bourse, M. (2009). Melezliğe Övgü (I. Ergüden, Çev.). İstanbul: Ayrıntı.

Buckingham, J.S. (1827). Travels in Mesopotomia. London: H. Colburn.

Bulaç, A. (2009). Bir Arada Yaşama Tecrübesi Mardin Modeli. Türkiye'de Birlikte Yaşama Kültürü ve Mardin Örneği içinde (s.139-153). T.C. Mardin Valiliği.

Burke, P. (2011). Kültürel Melezlik (M. Topal, Çev.).i̇stanbul: Asur.

Dolapönü, H. (1972). Tarihte Mardin. P. C. Aydın (Yay. haz.). İstanbul: Hilal Matbaacılık.

Doğan, M. (2008). Büyük Türkçe Sözlük (4. bs.). İstanbul: Pınar.

Doğruel, F. (2013). Hatay'da Çoketnili Ortak Yaşam Kültürü (3. bs.). İstanbul: iletişim.

Doytcheva, M. (2009). Çokkültürlülük (T. A. Onmuş, Çev.). İstanbul: illetişim.

El-Batâyine, M. D. (2000). Arap Kökenli Hıristiyanlar ve İslam Fetihleri ile Olan iliş̧kileri (A. Bakır, Çev.). Belleten, Aralık 1999, Cilt. 63 (238), 869-934.

Eriksen, T. H. (2004). Etnisite ve Milliyetçilik: Antropolojik Bir Bakış (E. Uşaklı, Çev.). Ankara: Avesta Basın Yayın.

Eriksen, T. H. ve Nielsen, F. S. (2014). Antropoloji Tarihi (4.bs., A. Bora, Çev.). İstanbul: Iletişim.

Göktaş, H.R. (2016). Bensenoğ: Türkçenin Ruhu. İstanbul: Külliyat.

Göle, N. (2008). Melez Desenler (3. bs.). İstanbul: Metis.

Graeber, D. (2017). Değer Teorisi (B. Kıcır, Çev.). İstanbul: Sel.

Güvenç, B. (1994). Insan ve Kültür. İstanbul: Remzi.

Halliwell, Martin (2007). American Culture in the 1950s. Edinburgh: Edinburgh Universtiy.

Hançerlioğlu, O. (2012). Felsefe Ansiklopedisi (5. Baskı, Cilt. 4). İstanbul: Remzi.

Hortaçsu, N. (2007). Ben Biz Siz Hepimiz: Toplumsal Kimlik ve Gruplararası İlişkiler. Ankara: İmge.

Kalın, í. (2016). Ben, Öteki ve Ötesi (5. bs.). İstanbul: İnsan.

Karlığa, B. (2009). İslam ve Batı Dünyasında Çoğulculuk ve Birlikte Yaşama Tecrübesi. Türkiye'de Birlikte Yaşama Kültürü ve Mardin Örneği içinde (s.2733). T.C. Mardin Valiliğ̈i.

Kearney, R. (2012). Yabancılar, Tanrılar ve Canavarlar: Ötekiliği Yorumlamak (B. Özkul, Çev.). İstanbul: Metis.

Kılıçbay, M. A. (1998). Siyasetsiz Siyaset. Ankara: İmge.

Kymlicka, W. (2015). Çokkültürlü Yurttaşlık (2. bs., A. Yılmaz, Çev.). İstanbul: Ayrıntı.

Omay S. B. ve Dinç, F., (2009). Mardin Tasavvuf Geleneğinin Birlikte Yaşama Kültürüne Katkıları. Türkiye'de Birlikte Yaşama Kültürü ve Mardin Örneği içinde (s.75-85). T.C. Mardin Valiliği.

Ortaylı, ì. (2001). Osmanlı Toplumunda Aile (3. bs.). İstanbul: Pan. 
Özcoşar, i. (2005). Osmanlı Devleti'nde Millet Sistemi ve Süryani Kadimler. A. Taşğın, E. Tanrıverdi ve C. Seyfeli (Yay. haz.). Süryaniler ve Süryanilik içinde (Cilt. II, s. 209-238). Ankara: Orient.

Özcoşar, í. (2009). Etnik ve Dinsel Sınırlar Bağlamında Mardin. Türkiye'de Birlikte Yaşama Kültürü ve Mardin Örneği içinde (s.101-105). T.C. Mardin Valiliği.

Özcoşar, i (2017). Şehir ve Kimlik: Mardinli Kimliklerin Tarihi Arka Planı. Kadim Akademi Sosyal Bilimler Dergisi, 1(1), s.1-29.

Özmen, A. (2006). Turabdin Süryanileri Örneğinde Etno-Kültürel Sınırlar. Yayımlanmamış doktora tezi, Ankara Üniversitesi, Ankara.

Öztürk, A. (2006). 19. Yüzyıl Mardin'de Müslim-Gayrimüslim İlişkilerine Örnekler. i. Özcoşar (Ed.). I. Uluslararası Mardin Tarihi Sempozyumu 26-27-28 Mayıs 2006 içinde (s. 519-524). Mardin.

Sarı, E. (2010). Mardin'de Kültürlerarasılık. İstanbul: iletişim.

Seyfeli, C. (2005). Osmanlı Devleti'nde Gayrimüslimlerin İdari Yapısı. A. Taşğın, E.Tanrıverdi ve C. Seyfeli (Yay. haz.). Süryaniler ve Süryanilik içinde (Cilt I, s.251-265). Ankara: Orient.

Shaw, S. (1985). Osmanlı İmparatorluğu'nda Azınlıklar Sorunu. A. Günlük (Çev.). Tanzimat'tan Cumhuriyet'e Türkiye Ansiklopedisi içinde (Cilt. 4, s. 1002-1006). İstanbul: İletişim.

Soykan, T. (2000). Osmanlı İmparatorluğunda Gayri Müslimler. Nuri Bilgin (Der.). İstanbul: Bağlam.

Su, S. (2009). Hurafeler ve Mitler. İstanbul: iletişim.

Şer, A. (2002). Siirt Vakayinamesi (C. Kabadayı, Çev.). İstanbul: Yaba.

Tarhan, N. (2010). Toplum Psikolojisi (2. bs.). İstanbul: Timaş.

Taylor, C., Appiah, K. A., Habermas, J., Rockefeller, S. C., Walzer, M. ve Wolf, S. (2014). Çokkültürcülük (4. bs.). A. Gutman (Yay. haz.). İstanbul: Yapı Kredi.

Türkdoğan, O. (1999). Etnik Sosyoloji (3. bs.). İstanbul: Timaş.

Yalap, A. (2011). Bizim Köyün Papazıdır. İstanbul: İletişim.

Yapıcı, A. (2004). Din Kimlik ve Ön Yargı. Adana: Karahan.

Yeşilmen, H. (2017). Mahallemiler: Değişim-Kimlik-Din. Konya: Çizgi.

Yuvalı, A. (1996). Mozaik Kültür Kavramının Türk Kültür Tarihi Bakımından Değerlendirilmesi. Erciyes Üniversitesi Sosyal Bilimler Enstitüsü Dergisi, 7, 211-217. 